\title{
Sour cherry for fresh consumption in the retail sector A consumer aspect
}

\author{
Felföldi, J. \& Apáti, F. \\ Department of Farm Business Management, Faculty of Agricultural Economic and Rural Development, \\ Centre for Agricultural Sciences, University of Debrecen, 138 Böszörményi St., H-4032 Debrecen Hungary
}

\begin{abstract}
Summary: The basic objective of our study is the promotion of fresh consumption of sour cherry and the enhancement of necessary knowledge. Primer collection of data was planned in three groups of retail shops, always sour cherry being the matter of study. The sampling dates were adapted to the sour cherry season weeks in Hungary. Three samples per week have been taken. Every time a short interview and purchase was planned. Every time, it was stated that the commodity was held for a longer period on the shelf, which trespasses the optimum of the fruit. At the same time there was no concordance between quality and price. From the point of view of the consumer this cannot be accepted.
\end{abstract}

Key words: sour cherry, fresh consumption, retail shops, quality

\section{Introduction}

Entrepreneurs in the fruit branch are not sufficiently provided with capital in order to encourage the buyers of each commodity. At the same time, not only the lack of information but the misinterpretation of them diverts the decision makers. All the same, the information available is insufficient, and the people let themselves satisfy by the stereotypic contentions, which is rather dangerous in a competitive situation. In questions of production and quality in the stone fruit branch, Szabó et al. (2010) published the actualities, whereas Apáti \& Gonda dealt with the future of sour cherry.

The acceptance of the produce offered and the stimulation of the demand need information, which is not available, therefore, we are rather confined to our own research. The majority of primary information is a result of observations, one part of it is based on responses collected. Fruit consumption in Hungary has been explored by Vanczák et al. (2002). The occurrence of conscientious buyers and habits related to fruit consumption are targets of the market research (TNS, 2009). The yearly consume per capita is for all fruits 45 $\mathrm{kg}$, for sour cherry, it is about $1 \mathrm{~kg}(K S H, 2009)$. Compared with the data of 2002, it displays a reduction to its half. This regrettably small quantity of fresh consumption ought to be increased by all means. As an objective of our study, the theoretical possibilities of amplification of consume should be considered to be an actual program. In the present study, the offer of sour cherry on the retail market has been explored.

\section{Materials and methods}

We have collected primary data, and classified the retail dealer into three categories. Sour cherry sold for fresh consumption during the season was the special objective. The three categories are: the small fruit and vegetable shops; the mediocre are members of some shop networks; the large shops are the super- and hyper-markets. Not only the magnitude of the enterprises justified this groups, but also the way how they build up and gather their supply. This latter property was also decisive and different from each other. The primary data are supplemented by questioning also in order to fill up the gaps, which were otherwise unanswered. Those types of information could not be acquired or only hardly by other methods (Hoffmann et al., 2001). The sampling dates were distributed over the Hungarian sour cherry season, and comprised three samples per week. Experimental shopping and occasionally an interview completed the inquiry. Each offer studied has been completed by information dealing with packing and eventually some definition of quality. Three units per group, altogether 9 samples have been taken every time. Also the freshness of the samples has been determined on the spot.

\section{Results}

Some of the samples of fresh sour cherries found in different shops are distinguished by their special value. There is as a special case, a package, where the variety and the producing country was marked (see Table 1)

For the small enterprises, the deficient information was typical. Neither variety nor origin was marked, moreover, the time spent on the shelf could not be determined. The dealers were similarly ignorant, and they sell it without package. The same deficient marks are also found in some shopping networks. Fruit packed in trays used to exhibit the information necessary. 
Table 1. Characteristic qualities of sour cherries packed for fresh consumption in the retail markets

\begin{tabular}{|c|c|c|c|c|c|c|}
\hline $\begin{array}{l}\text { Category } \\
\text { of the retail } \\
\text { market }\end{array}$ & package & qualiy & variety & origin & marking & consistency/state \\
\hline \multirow[t]{2}{*}{ Small } & in bulk & I.class & unknown & unknown & deficient & \multirow{5}{*}{$\begin{array}{l}\text { The commodity is held } \\
\text { on the shelf for a to long } \\
\text { period, typical marks: } \\
\text { fruit flies, stale impression, } \\
\text { sticky, taste fermented, } \\
\text { bitter, etc. }\end{array}$} \\
\hline & in bulk & II.class & unknown & unknown & deficient & \\
\hline Mediocre & trays & I.class & well known & Hungarian & acceptable & \\
\hline \multirow[t]{2}{*}{ Large } & trays & I.class & well known & Hungarian & acceptable & \\
\hline & in bulk & II.class & well known & Hungarian & deficient & \\
\hline
\end{tabular}

Source: original

In all markets, the commodity was held for a too long period on the shelf, in spite of the dwindling quality. The buyer will gain an unfavourable impression, which discourages him. The appearance of fruit flies, stale impression, the fruits are visibly sticky and taste as fermented or bitter. Sometimes also flies are appearing in the trays. The merchandise is really not attractive.

Table 2. The quantitative characteristics of sour cherry offered for fresh consumption in different detail markets

\begin{tabular}{|l|l|l|l|l|l|}
\hline $\begin{array}{l}\text { Category of } \\
\text { the retail } \\
\text { market }\end{array}$ & package & quality & $\begin{array}{l}\text { consumer's } \\
\text { price Ft/kg }\end{array}$ & $\begin{array}{l}\text { fruit with } \\
\text { stem mean } \\
\text { weight } \\
\text { (gram) }\end{array}$ & $\begin{array}{l}\text { ratio of } \\
\text { stemless } \\
\text { fruits \% }\end{array}$ \\
\hline \multirow{2}{*}{ Small } & in bulk & I.class & $300-499$ & 5.3 & $1-2.5$ \\
\cline { 2 - 6 } & in bulk & II.class & $249-299$ & 5.3 & $2-2.5$ \\
\hline Mediocre & trays & I.class & $338-529$ & 4.4 & $1.5-2.9$ \\
\hline \multirow{2}{*}{ Large } & trays & I.class & $398-598$ & 4.4 & $1.1-2.2$ \\
\cline { 2 - 6 } & in bulk & II.class & $499-549$ & 4.1 & $1.1-2.2$ \\
\hline
\end{tabular}

Source: original

We did not find causal relation between the consistence of the commodity and its price (Table 2). The distinction between first and second class of quality does not seem to be consistent. It happened also that the second class proved to be better than the first class batch of fruit. Prices did not reflect the quality. The small shops, however, offered as a mean larger fruits than the other two category of shops. We may ask the question, whether fruits packed in trays are smaller than those sold in bulk? However, we do not want to

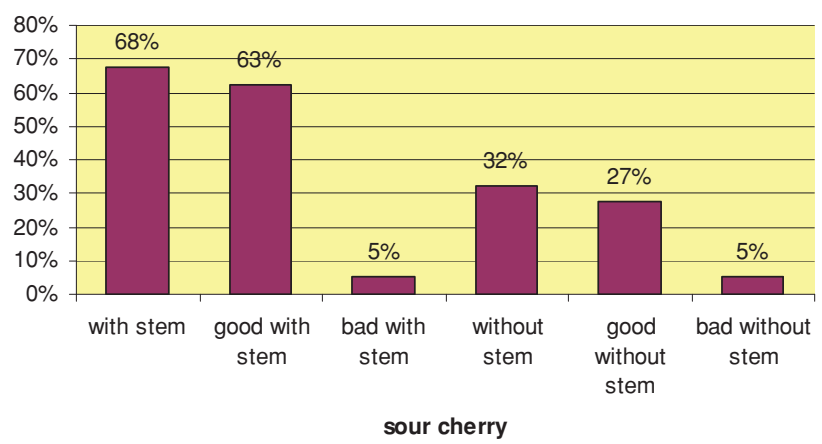

Figure 1. Distribution of the sour cherry offered with stem and without stem, of good and of bad quality in small shops

Source: original formulate conclusions, the question requires further exploration as for the effect of package.

The small retail shops offered the fruit with stem $68 \%$ and without stem $32 \%$ (Figure 1). The fruits with stem were mostly of good quality (63\%), less were of bad quality (5\%) related to the large average. The stem less fruits (32\% of the mass) had good (27\%) and bad (5\%) quality.

In the mediocre size of retail shops, the results are presented in Figure 2. according to the same categories as in Figure 1. Fruit with stem was $71 \%$, without stem $29 \%$; within them $25 \%$ was of good quality, $46 \%$ of bad quality. The $6 \%$ of stem less were of good quality, $24 \%$ of bad quality.

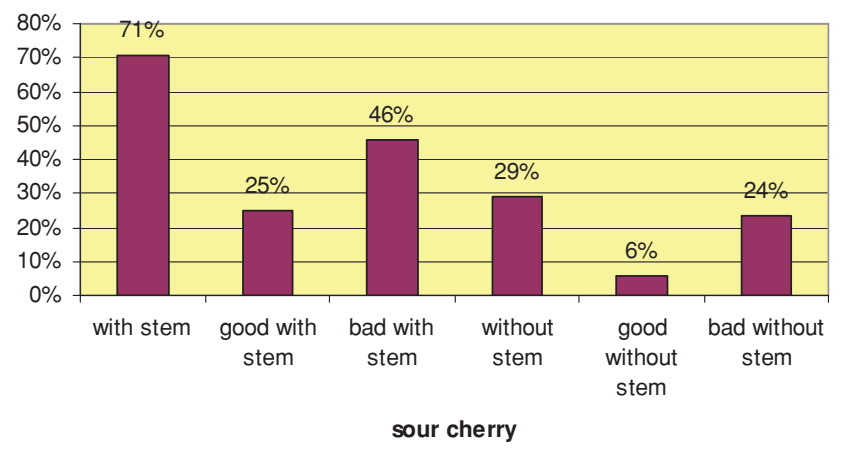

Figure 2. Distribution of the sour cherry offered with stem and without stem, of good and of bad quality in mediocre shops Source: original

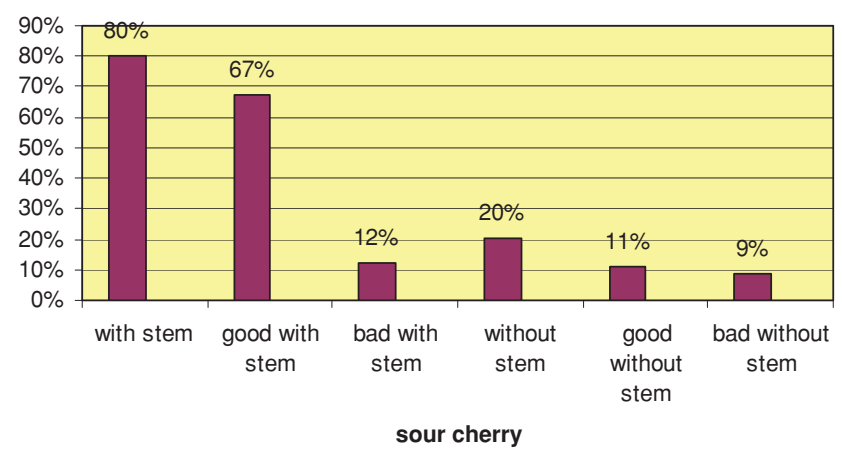

Figure 3. Distribution of the sour cherry offered with stem and without stem, of good and of bad quality in super-and hipermarkets Source: original

In the large super-, and hiper-markets, the results are presented in Figure 3 according to the same categories as in Figure 1. Fruit with stem was $80 \%$, without stem $20 \%$; within them $67 \%$ was of good quality, $12 \%$ of bad quality. The $11 \%$ of stem less were of good quality, $9 \%$ of bad quality.

The comparison of the three different size of retail shops regarding the quality of sour cherry offered resulted as shown in Figure 4. The most conspicuous is the relatively bad quality of the commodity offered by the mediocre size of retailers. The supposed cause of it is that the shopkeepers 
hold their offer even for a longer time on shelf, where the decay started. On the contrary, the small shops have been much more attentive, but the super- and hypermarkets offered about $20 \%$ bad quality, which is worse than the average.

As for the prices, the small shops sell low quality fruit for 25-50 Ft/kg, whereas high quality fruit could be sold for 250-500 Ft/kg depending on the size of the fruits. The mediocre size shops may raise prices beyond $300 \mathrm{Ft} / \mathrm{kg}$. In the large sector we are also exposed to the risk of buying bad quality for $80-120 \mathrm{Ft} / \mathrm{kb}$.

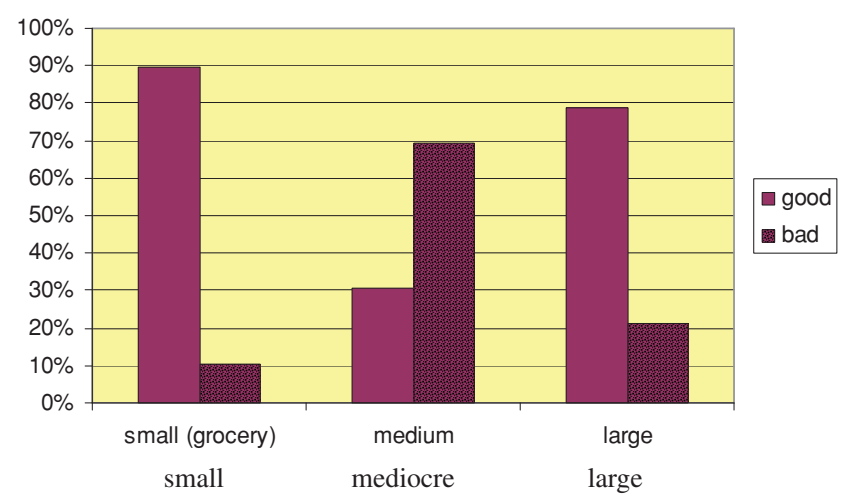

Figure 4. The distribution of quality in sour cherry offered in retail markets of different size

Source: origina

The high quality of sour cherry is associated with the presence of fruit stem. Therefore the stem less fraction around $20-30 \%$ seems to be too large. Fruit stem is a criterion of fruit quality, therefore the best rate $(20 \%)$ is in the large shop category is still unacceptable (Figure 5).

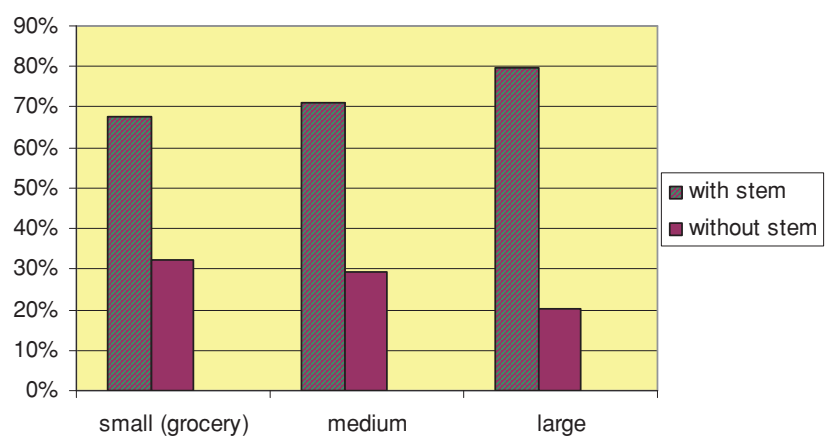

Figure 5. The rate of sour cherry fruits offered with stem and without stem in three different size categories of retail shops

Source: original

Essentially, the quality found in all categories was unacceptable and should be improved.

The package and the quality of the offered commodity is illustrated by photographs in Supplement I.

\section{Conclusions, suggestions}

Our experiences are shortly summarised: the commodity is held on the shelf for a longer time than allowed by the shelf life of sour cherry. The buyer is not encouraged but rather discouraged by the sight already. At the same time, there was no evident correlation between the quality and the prise of the goods offered. The qualification of first and second class was not consequently expressed neither in the price. The differences between the three categories of the shop size were not consequent and not essential. In order to improve the commerce of sour cherry, we suggest the following actions.

From the point of view of the supplier, a clearly distinct classification of the commodities is recommended because the mixed good is associated with an unfavourable bargaining position. Expectations of the consumers, traditions, prejudices are also active causes in the expression of exigencies.

Distribution, circulation and delivery (to the consumer) ought to be performed, depending on the possibilities, to meet with the demands in the physical and temporary sense. The present status needs to be decided whether the present system and the existing canals are they sufficient to fulfil the due expectations? How long is they chain from the grower to the consumer (the mediators and distributors), who contribute to the value of the commodity and service with their participation. Each member ought to be evaluated individually. It should be decided whether the present system can it be improved and what are the points to be changed for a more efficacious one.

\section{Acknowledgements}

This paper was supported by the János Bolyai Research Scholarship of the Hungarian Academy of Sciences.

\section{References}

Apáti, F. \& Gonda, I. (2010): The future of the Hungarian sour cherry growing branch. Int. J. Hort. Sci., 16, (1): 99-104.

Hoffmann, M., Veres, Z. \& Kozák, Á. (2001): Piackutatás. Müszaki Kiadó, Budapest

KSH (2009): Egy főre jutó évi élelmiszerfogyasztás (2002-2007). ksh.hu

Szabó, Z., Soltész, M., Apáti, F., Nyéki, J. (2010): Conditions and outlooks of growing stone fruits. Int. J. Hort. Sci., (16): 1: 91-98.

TNS (2009): Vásárlói tudatosság. Progresszív Magazin. Crier Media Csoport, 17 (4): 50. p.

Vanczák, E., Takácsné György, K. \& Komáromi, N. (2002): A gyümölcs- és almafogyasztás helyzete, egy kérdőíves felmérés eredményei. Kertgazdaság, 34. (2): 55-60. 


\section{Supplement I}

The make up of sour cherry for the shops of retail market showing its package and quality in pictures

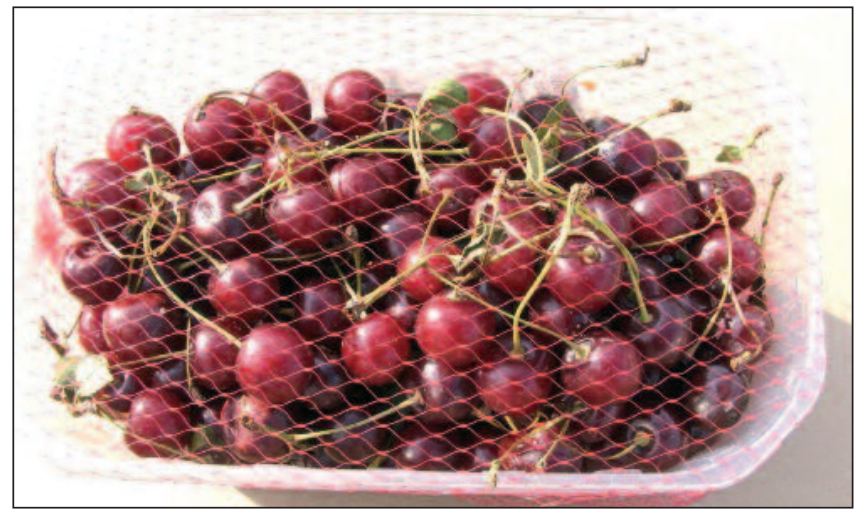

Supplement 1. Sour cherry with a high rate of fruits without stem

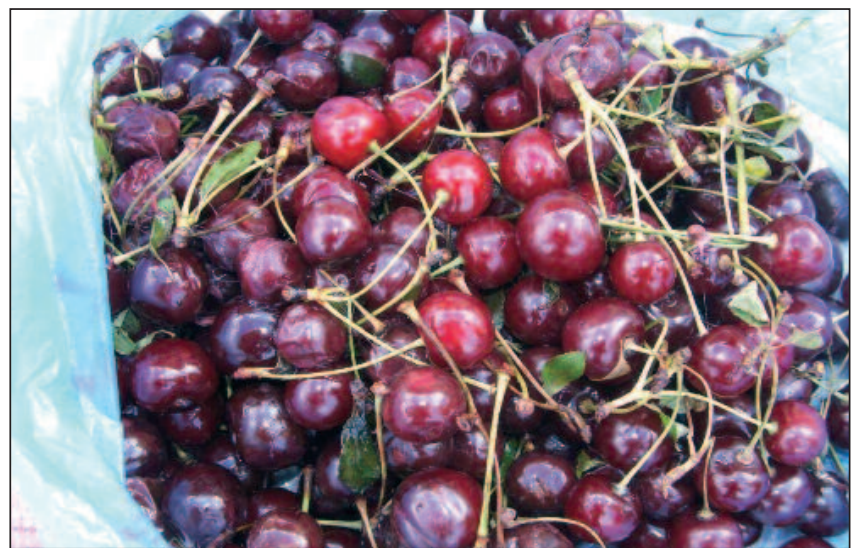

Supplement 3 . Sour cherry offered in bulk with many wilt fruits and bracts

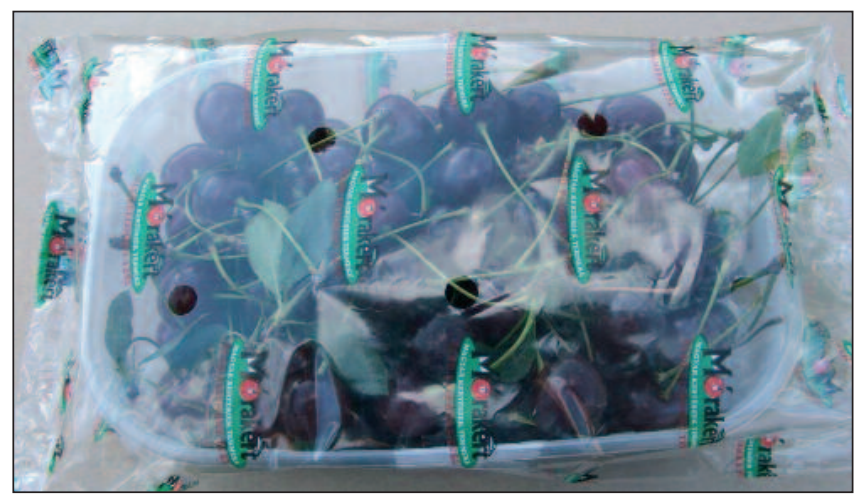

Supplement 5. Commodity of standard quality offered by a good supplier

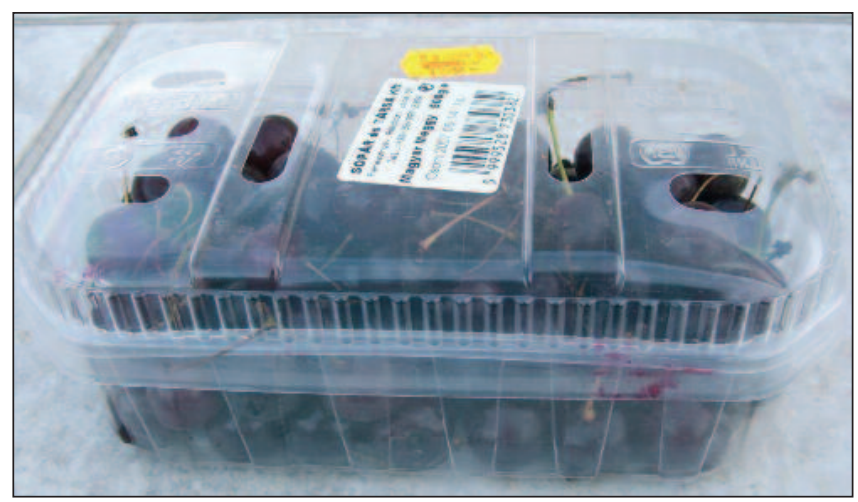

Supplement 7. Practical package but low quality

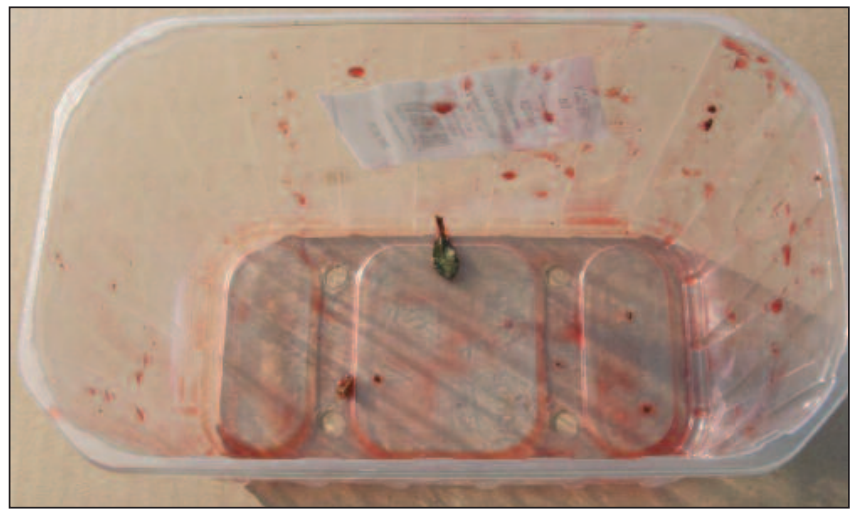

Supplement 2. Sour cherry having been held on the shelf for more than $\mathbf{8}$ days -its quality declined conspicuously, got sticky, and its juice have been released

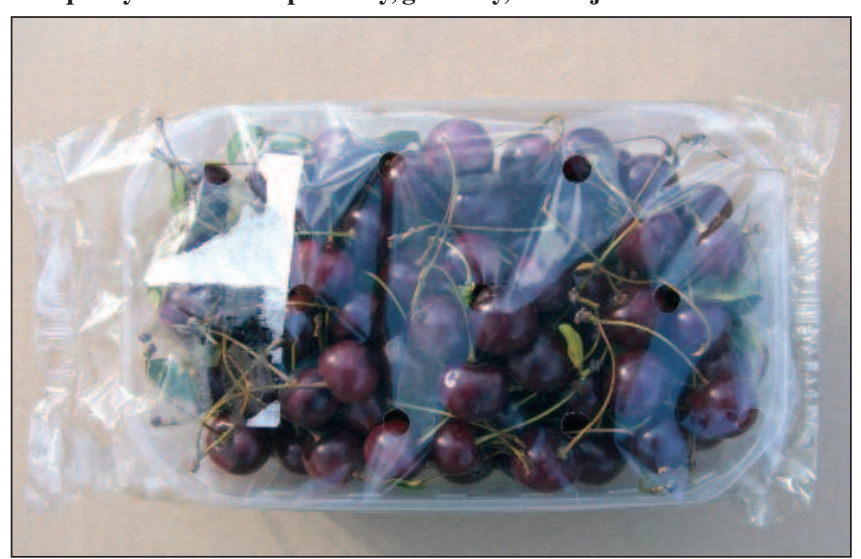

Supplement 4. Practical package, good quality

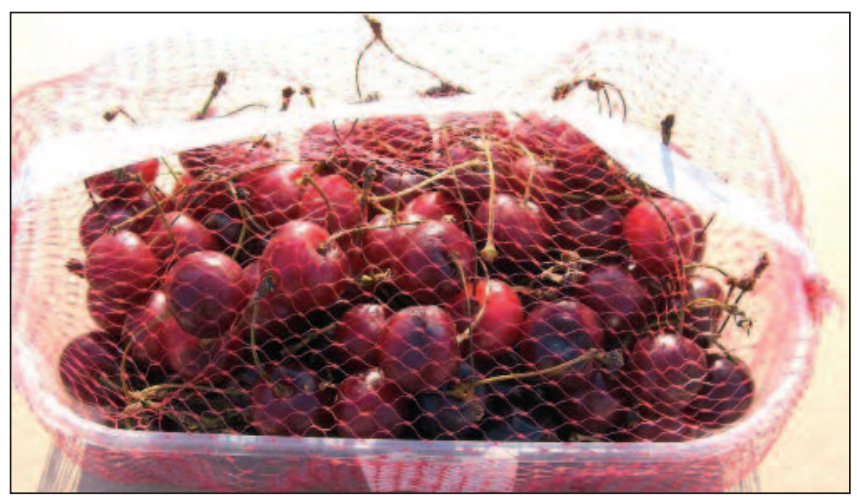

Supplement 6 . Frequently applies package: $\mathbf{5 0 0} \mathrm{g}$ trays with a net

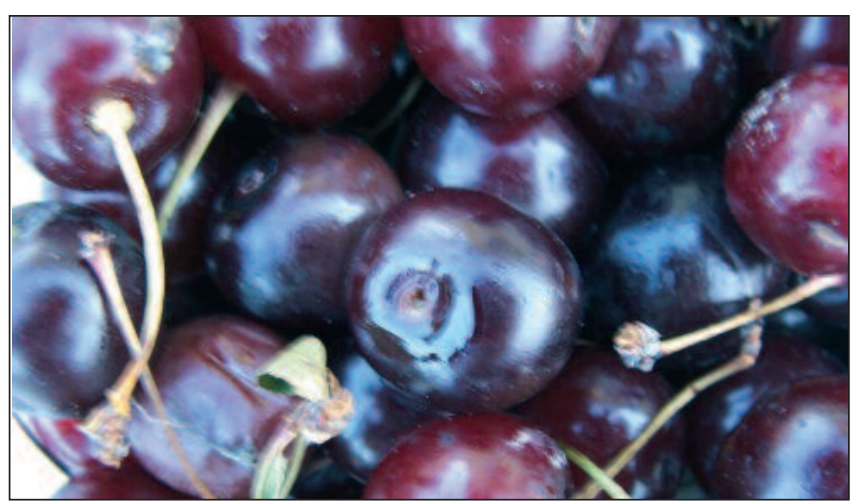

Supplement 8. A frequent phenomenon on the shelf of shops: juicy and wilted fruits 